\title{
INTERAKSIONISME SIMBOLIK DALAM KAJIAN SEJARAH
}

\author{
Debi Setiawati ${ }^{1}$ )
}

\begin{abstract}
Abstrak
Ilmu sejarah sebagai bagian dari ilmu sosial membutuhkan teori interaksionisme simbolik dalam mengungkap kebenaran peristiwa masa lampau. Teori tersebut memiliki peran dalam mengungkap dan memaknai simbol-simbol yang terdapat di dalam setiap realitas kehidupan manusia. Oleh sebab itu makna dan kebenaran yang ada di setiap peristiwa sejarah dapat diungkap secara utuh dan menyeluruh, sehingga memiliki hubungan keterkaitan dan bersifat integral yang tidak dapat dipisahkan. Seorang guru sejarah memiliki peran penting dalam proses pembelajaran sejarah, maka dibutuhkan kesadaran yang tinggi dalam menginterpretasi makna yang ada dalam peristiwa-peristiwa sejarah secara obyektif.
\end{abstract}

Kata kunci: Interaksionisme Simbolik, Peristiwa Sejarah, Guru Sejarah 


\section{Pendahuluan}

Sejarah sebagai salah satu bagian dari Ilmu Sosial dalam penelitiannya sering menggunakan metode kualitatif. Hal tersebut disebabkan dalam ilmu sejarah banyak mengkaji peristiwa-peristiwa yang telah terjadi dalam kehidupan manusia, yang dikaitkan atau dicari relevansinya dengan kondisi manusia pada saat ini atau bersifat kekinian. Datanya berupa fenomena yang mengikuti aliran fenomenologi yang tidak membutuhkan data statistik, hanya menggunakan data sederhana yang disebut idiografis yaitu suatu tanda berkemungkinan banyak makna.

Memahami fenomena-fenomena sosial yang didalamnya memuat banyak aspek seperti tingkah laku manusia, tidak cukup dengan hanya merekam apa yang nampak secara eksplisit (surface behaviour), melainkan harus melihat secara keseluruhan dalam totalitas konteksnya. Untuk itu dibutuhkan sebuah metode disiplined inquiri yang lebih tipologis dan sifatnya holistic dengan memperhatikan keunikan manusia yang tidak dapat disederhanakan menjadi suatu kumpulan variabel yang memiliki batasan-batasan yang bersifat deterministic (Herman J. Waluyo, 2002:35).

Realitas sosial yang bersifat maknawi mengandung perspektif subyektif. Sesuatu dalam pandangan dan persepsi seseorang merupakan kesadaran sosial dan budaya yang diperoleh melalui proses inferensi dari rentangan pengalaman social budaya yang beraneka ragam dan berbeda antara manusia satu dengan yang lain, serta kelompok satu dengan kelompok lain. Dengan demikian keragaman dan keunikan tingkah laku antar orang atau kelompok tetap terlihat dengan jelas, kapanpun dan dimanapun.

Melihat kenyataan tersebut, maka dibutuhkan adanya metode disiplined inquiry secara mendalam hingga ke tingkat inner behavior agar perspektif makna bersifat integral yaitu menjadi satu kesatuan yang bulat dalam menelaah fenomena sosial dan tingkah laku manusia. Tulisan ini akan mengkaji lebih lanjut peran teori interaksionisme simbolik dalam kajian sejarah.

\section{Interaksionisme Simbolik Dalam Kajian Teori}

Interaksionisme simbolik merupakan sebuah teori yang berusaha menjelaskan tingkah laku manusia melalui analisis makna. Teori ini berakar pada karya-karya ahli sosiologi seperti: Charles Horton Cooley, George Hebert Mead, Robert Park, Florion Znanicld dan W.I. Thomas (Sanapiah Faisal, 1990:1415).

George Herbert Mead menyatakan bahwa prasyarat utama yang diperlukan untuk mencapai proses pemersatuan sebagai segmen masyarakat adalah simbol-simbol yang dibagi bersama, maka orang harus berpegang pada definisi-definisi yang 
kurang lebih sama dalam mewujudkan suatu kebersatuan kultural (Veeger, 1990:229).

Menurut Ritter (2004:289) Ciriciri utama teori interaksionisme simbolik adalah sebagai berikut:

1. Manusia memiliki kemampuan untuk berpikir, hal itulah yang membedakannya dengan binatang.

2. Kemampuan berpikir itu terbentuk melalui proses interaksi sosial.

3. Dalam interaksi sosial manusia, mempelajari arti dan makna simbol-simbol yang akan meningkatkan kemampuan berpikirnya.

4. Atas dasar penafsiran dan kondisi yang dihadapi manusia akan mengubah arti dan makna simbol-simbol.

5. Pola-pola tindakan dan interaksi yang saling berhubungan yang membentuk kelompok dan masyarakat.

Dengan demikian orang tidak hanya berinteraksi dengan orang lain, tetapi secara simbolis juga berinteraksi dengan dirinya sendiri. Interaksi simbolis ini dilakukan dengan menggunakan bahasa yang merupakan sistem sosial yang paling luas, kaya dan canggih.

Pandangan Blumer (Dahtm Poloma, 1994: 261) teori interaksionisme simbolik bersandar pada tiga premis yang dirumuskan sebagai berikut:

1. Manusia bertindak kearah sesuatu atas dasar makna yang melekat pada sesuatu itu, artinya pada sesuatu itu ada makna dan sesuatu itu sekedar simbol dari makna dan tindakan manusia ditujukan untuk mengejar makna.

2. Makna tersebut berkembang melalui interaksi antar manusia dalam kehidupan sehari-hari. Hal tersebut sejalan dengan arus perkembangan budaya itu sendiri sebagai suatu hasil yng membagi sistem makna dengan mempelajari, memperbaharui, memelihara dan membatasi makna tersebut dalam konteks interaksi manusia. Oleh karena itu makna tersebut membawa dampak yang sangat berarti terhadap tingkah lakunya dan juga tingkah laku orang lain terhadapnya.

3. Makna-makna tersebut dipegang, dijadikan acuan dan diinterpretasikan oleh seseorang dalam berhubungan dengan sesuatu yang dihadapinya. Ia gunakan sebagai acuan untuk menafsirkan suatu situasi, keadaan, benda atau lainnya dalam kehidupan seharihari.

Pendapat Francis Abraham dalam Modern Sociological Theory bahwa interaksionisme simbolik pada hakikatnya merupakan sebuah perspektif yang bersifat sosialpsikologis yang terutama relevan untuk penyelidikan sosiologis. Teori ini akan membahas tentang struktur sosial dan bentuk kongkret dari perilaku individual atau sifat-sifat batin yang bersifat dugaan. Interaksionisme simbolik juga memfokuskan pada hakekat interaksi serta pola dinamis dari tindakan sosial dan hubungan sosial. Semua interaksi antar individu akan melibatkan pertukaran simbol yang memiliki makna. Interaksionisme 
simbolik menekankan pada makna yang tercakup dalam cara manusia menggunakan dan menginterpretasikan pola-pola simbolik dalam melakukan interaksi sosial dalam masyarakat (Riyadi Suprapto dalam http://www.averroes.or.id/research Lteori-interaksionisme-

simbolik.html).

Teori interkasionisme simbolik memiliki kegunaan sebagai sarana untuk mempelajari tingkah laku manusia atau memahami tingkah laku manusia, yang mana tingkah laku manusia bersifat maknawi atau ada sistem makna dibalik setiap tingkah laku manusia. Untuk dapat menafsirkan makna tersebut dibutuhkan pendekatan yang integral dalam teori interaksionisme simbolik.

Interaksionisme simbolik merupakan salah satu model penelitian budaya yang berusaha mengungkap realitas perilaku manusia. Perspektif interaksi simbolik berusaha memahami budaya lewat perilaku manusia yang terpantul dalam komunikasi. Interaksi simbolik lebih menekankan pada makna interaksi budaya sebuah komunitas. Makna esensial akan tercermin melalui komunikasi budaya antar warga setempat. Pada saat berkomunikasi manusia banyak menampilkan simbol-simbol yang memiliki banyak makna, sehingga perlu dilakukan pengamatan untuk dapat menemukan maknanya (http://www.fkip.uki.ac.id/index.ph p?option.com.content\&view.article\&i d.78:penelitian.lintas.budaya\&catid.4 1).
Menurut pendapat Goerge Herbert Mead menyatakan bahwa Interaksionisme simbolik itu memiliki ide dasar sebuah simbol, karena simbol tersebut merupakan konsep mulia yang membedakan manusia dari binatang. Simbol ini muncul akibat dari kebutuhan setiap individu untuk berinteraksi dengan orang lain. Komunikasi manusia berlangsung melalui pertukaran serta pemaknaan simbol. (http://www.kikyo.blog.uns.ac.id/20 10/04/03/interaksionismesimbolik).

Menafsirkan simbol-simbol yang terdapat dalam fenomena sosial dan budaya, yang mana fenomena sosial dan budaya merupakan tempat berlangsungya interaksi antar manusia yang menghasilkan simbolsimbol yang memiliki makna tertentu. Untuk itu dibutuhkan teori teori interaksionisme simbolik untuk menafsirkan makna yang terdapat dibalik simbol-simbol tersebut. Oleh karena itu dalam memahami fenomena sosial budaya serta tingkah laku manusia secara benar dan utuh dibutuhkan suatu metode yang spesifik yang maknanya dapat dilihat secara eksplisit.

\section{Interaksionisme Simbolik dalam Kajian Sejarah}

Sejarah merupakan rangkaian peristiwa yang terjadi pada masa lampau yang dialami manusia. Masa lampau merupakan unsur yang sangat penting dalam sejarah dan konteks waktu merupakan bagian yang tak terpisahkan dalam ke- 
hidupan manusia. Dengan demikian waktu dalam sejarah akan melahirkan perspektif tentang berbagai peristiwa yang akan terjadi dan sekaligus sesuatu yang secara menonjol mampu menunjukkan kebesaran peristiwa masa lampau. Sejarah tidak akan memiliki makna apabila segala sesuatu dalam keadaan tetap, sehingga akan selalu terjadi perubahan sesuai dengan ruang dan waktu.

Sejarah juga mengkaji manusia dalam lingkup keruangannya baik sebagai individu maupun bangsa, sehingga manusia dipelajari dalam lingkungan fisik dan geo-grafis. Interaksi manusia dengan lingkungan akan berjalan dinamis apabila menghasilkan variasi perkembangan pada aktivitas manusia dan pencapaiannya dalam bidang politik, ekonomi, sosial dan kebudayaan.

Kontinuitas dan keterkaitan merupakan hal yang sangat penting dalam sejarah, sehingga suatu peristiwa itu lahir dipengaruhi oleh peristiwa yang telah terjadi sebelumnya. Sedangkan peristiwa yang terikat dengan kejadian masa lampau akan terus berkembang seiring dengan peristiwa lain yang saling berhubungan atau memiliki sifat kausalitas atau sebab akibat. Ada tiga unsur penting yang terdapat dalam kajian sejarah yaitu:

1. Manusia

Merupakan subjek atau pelaku dalam peristiwa-peristiwa sejarah sehingga di dalamnya memuat tingkah laku manusia yang memiliki banyak makna.
2. Tempat

Merupakan lokasi terjadinya peristiwa-perstiwa sejarah, yang merupakan realitas sosial yang memiliki simbol-simbol yang perlu ditafsirkan agar memiliki makna.

3. Waktu

Merupakan batasan waktu terjadinya suatu peristiwa sejarah (Kuntowijoyo, 1996:33).

Dari ketiga unsur penting di atas memiliki hubungan saling terkait yang tidak bisa dipisahkan sebab dalam menganalisis terjadinya suatu peristiwa sejarah ketiga unsur tersebut selalu ada dan sebagai kunci untuk mengungkap lebih lanjut apa yang terjadi di balik peristiwa tersebut.

Untuk mengungkap kebenaran dalam suatu peristiwa sejarah perlu dilakukan penelitian dengan disertai data atau sumber yang memiliki otentisitas dan kredibilitas yang sangat tinggi, yang mana dalam penelitian sejarah memiliki langkahlangkah sebagai berikut:

1. Heuristik

Tahap pengumpulan data yang relevan atau mencari dan mengumpulkan sumber-sumber yang relevan dengan topik atau judul sejarah. Dalam pengumpulan sumber ini perlu dibedakan antara sumber primer dengan sumber sekunder.

2. Verifkasi

Tahap pemeriksaan dan penilaian terhadap kebenaran sumber-sumber. Dari sumbersumber yang terkumpul diklasifikasikan berdasarkan keaslian materi dan relevansi sumber itu 
dengan masalah yang akan dibahas, sehingga dikenal dengan istilah kritik intern dan ekstern.

3. Interpretasi

\begin{tabular}{lr}
\multicolumn{2}{c}{ Merupakan tahapan } \\
pemberian kesan, tafsiran, \\
pendapat atau padangan teoritis \\
terhadap suatu sumber sejarah \\
perlu diinterpretasikan atau
\end{tabular}
ditelaah. Di dalam menginterpretasikan sumber harus berpegang pada patokan yang berupa pandangan yang bersifat Indonesiasentris, yang akan diuraikan secara analitis dengan mementingkan hubungan kausalitas atau sebab akibat dan berkesinambungan yang didukung oleh pendekatan secara multidimensional.

4. Historiografi

Tahap penulisan sejarah yang merupakan laporan penelitian sejarah. Pada tahap ini sumber yang sudah diinterpretasi dan dianalisis dirangkaikan menjadi cerita sejarah. (Louis Gottschalk, 2006:33).

Di samping melalui empat langkah tersebut juga dibutuhkan suatu metode yang digunakan sebagai pedoman yang membatasi dan mengatur dalam langkahlangkah penelitian. Metodologi yang digunakan adalah metode kualitatif yaitu metode penelitian yang lebih humanistis sifatnya dalam memandang realitas sosial dengan menggunakan tori-teori seperti fenomenologi, interaksionisme simbolik dan etnometodologi .

Ilmu sejarah sebagai bagian dari ilmu sosial dalam penelitiannya menggunakan metodologi kualitatif.
Di dalam penelitian ini memiliki sifat unik dari realitas sosial dan tingkah laku manusia. Keunikannya bersumber dari hakekat manusia sebagai mahluk psikis, sosial dan budaya yang mengkaitkan makna dan interpretasi dalam bersikap dan bertingkah laku. Makna dan interpretasi tersebut ada karena dipengaruhi oleh lingkungan sosial dan budaya. Oleh karena itu terjadinya sistem makna yang kompleks dapat dipahami dan digunakan, oleh seseorang atau sekelompok orang dalam mengorganisasikan segenap sikap dan tingkah lakunya sehari-hari.

Di dalam penelitian sejarah teori interaksionisme simbolik digunakan untuk menginterpretasikan maknamakna yang terdapat dibalik peristiwa sejarah yang dikaitkan dengan tindakan para pelaku sejarah dengan menggunakan pendekatan multidimensional (dalam berbagai segi) yang merupakan gambaran realitas sosial terjadinya peristiwa sejarah. Dari makna yang telah diinterpretasikan dianalisis secara menyeluruh dengan makna hubungan kausalitas atau sebab akibat, sehingga dapat diperoleh suatu kebenaran yang merupakan kesimpulan atau hasil dari penelitian sejarah.

Implementasi interaksionisme simbolik dalam kajian sejarah tampak dalam hal-hal berikut ini:

1. Tindakan simbolis dalam religi

Sejarah perkembangan religi di Indonesia dimulai sejak zaman pra sejarah sampai dengan masuknya pengaruh agama Islam, masing masing memilki pengaruh yang kuat 
terhadap simbol atau lambang yang terdapat dalam kehidupan masyarakat seperti:

a. Masa Prasejarah

Pada masa prasejarah dipercayai adanya kepercayaan yang bersifat animisme dan dinamisme,sehingga semua benda yang ada di sekelilingnya memiliki nyawa atau roh. Oleh karena itu benda-benda tersebut hidup dan dapat bergerak. Roh yang bersemayam di setiap benda tersebut merupakan roh yang baik, maka sebagai wujud pemujaan di buat monumen peringatan yang di buat dari jenis batu besar dan halus atau dikenal dengan Menhir. Fungsi dari Menhir tersebut sebagai tugu pemujaan terhadap roh nenek moyang.

b. Pengaruh Kebudayaan Hindu

Kebudayaan Hindu di Indonesia juga memberi pengaruh yang sangat besar dalam tindakan simbolisme dalam religi yang bersifat polyteisme yaitu percaya kepada dewa-dewi. Hal tersebut nampak dalam kepercayaan terhadap Dewi Sri yang merupakan tokoh simbolik kaum petani yang melindungi tanaman padi terhadap gangguan hama. Di samping itu juga ada tokoh Bathara kala dan Sudamala yang merupakan simbol pembawa malapetaka bagi orang yang mempunyai ciri-ciri tertentu, maka untuk menghindarinya orang tersebut harus diruwat.

c. Pengaruh Kebudayaan Islam

Tindakan simbolis dalam religi yang merupakan pengaruh kebudayaan Islam nampak dalam rangkaian upacara peringatan Maulud Nabi Muhammad S.A.W. yang dilaksanakan oleh warga Keraton Ngayogyakarta Hadiningrat di Yogyakarta yang terkenal dengan upacara sekaten. Tindakan simbolis berupa melarung sepasang pakaian wanita persembahan dari Raja yang merupakan keturunan dari Panembahan Senopati telah berhasil mengawini Kanjeng Ratu Kidul yang merupakan Raja putri laut kidul atau samudera selatan yang sakti. Tindakan simbolis lainnya berupa pemandian keretakereta kerajaan. Bagi orang yang berhasil mencuci muka dengan sisa air yang dipakai untuk memandikan kereta tersebut akan mendapat berkah. Puncak dari tindakan simbolis dalam upacara sekaten berupa ditabuhnya gamelan keraton mengiringi upacara selamatan dengan dibagikannya tumpeng gunungan di pelataran Masjid Agung Karaton. (Budiono Herusatoto, 2008:163).

2. Tindakan Simbolis dalam Tradisi

a. Tindakan simbolis nampak dalam tradisi pembagian warisan di Jawa yang berlaku adanya simbol "sepikul segendongan", satu pikul dan satu bakul. Anak laki-laki mendapatkan bagian warisan "sepikul" atau dua per tiga bagian. Sedangkan anak perempuan mendapat bagian "sebakul" atau sepertiga bagian.

b. Tindakan simbolis nampak dalam tradisi upacara perkawinan orang Jawa seperti: nontoni yaitu me- 
lihat dari dekat calon menantu, nglamar yaitu keluarga laki-laki untuk diperkenankan mengambil anak perempuannya sebagai calon istri anak laki-lakinya, Peningset yaitu tanda pengikat sebagai simbol peresmian lamaran telah diterima, siraman dan midodareni yaitu sebagai simbol bahwa sejak saat itu telah meninggalkan masa perawan dan memasuki jenjang kehidupan orang dewasa.

c. Tindakan simbolis dalam tradisi upacara kelahiran di Jawa nampak dari adanya simbol berupa: Ngapati yaitu selamatan genap empat bulan, Mitoni yaitu selamatan genap tujuh bulan dan memenuhi harapan orang tuanya, Selapan yaitu selametan bayi berumur 35 hari disertai dengan pengundulan rambut, Tedak sinten atau turun tanah yaitu untuk melihat bakat si anak di kemudian hari, dengan melihat dari barang apa yang diambil.

d. Tindakan simbolis dalam tradisi gotong royong atau bekerjasama nampak dari simbol yang berupa ungkapan "saiyeg saeko proyo".

e. Tindakan simbolis dalam tradisi saling menghargai nampak dari simbol yang berupa ungkapan " Sapa gawe nganggo, sapo nandur ngunduh" yaitu siapa membuat akan memakai dan siapa menanam akan memetik hasilnya, artinya setiap perbuatan yang baik dan siapa menanam akan memetik juga, artinya semua perbuatan yang baik akan membuahkan kebaikan, sedangkan siapa yang mencelakakan orang lain, tentu suatu saat menerima akibatnya.

f. Tindakan simbolis dalam membatasi tata kelakuan manusia terutama dalam kebudayaan Jawa nampak dari ungkapan simbolis seperti "saiyeg saeko praya" artinya bergerak bersama untuk mancapai tujuan bersama, "mangan ora mangan kumpul" artinya makan tidak makan tetap bersama-sama, hal tersebut menggambarkan betapa kuat rasa senasib sepenanggungan akan dirasakan dan dilaksanakan bersama asalkan mereka tetap bersama-sama, " Jer Basuki Mawa Bea " artinya setiap kesejahteraan yang diinginkan tentu harus mengeluarkan biaya yang berupa uang, usaha, tenaga, pengorbanan perasaan atau waktu (Budiono Herusatoto, 2008:165-167).

3. Tindakan Simbolis dalam Seni

a. Pertunjukan wayang kulit maupun wayang orang memiliki banyak simbol dalam perwatakan manusia, baik yang memiliki watak baik maupun buruk yang nampak dari tokoh-tokoh yang dimainkan oleh dalang. Tokohtokoh tersebut diambil dari ceritera Ramayana maupun Mahabarata, yang merupakan warisan dari budaya India yang berakulturasi dengan Islam. Tokoh Arjuna merupakan simbol karakter atau perwatakan yang memiliki tanggung jawab, keberanian dan kejujuran sedangkan Duryudono merupakan simbol karakter atau perwatakan yang congkak, dengki dan 
serakah. Sebelum pertunjukan wayang dimulai harus di sediakan sesaji dan kenduri yang berupa bunga setaman, jajan pasar dan ingkung. Sesaji tersebut merupakan simbol untuk menolak bala bahaya yang mengancam dalam pertunjukan wayang.

b. Tindakan simbolis dalam seni tari nampak dalam seluruh gerak langkah serta pola-pola tarian. Setiap rangkain gerak dalam tarian merupakan penghalusan dari suatu pekerjaan ataupun sikap seseorang dalam menghadapi berbagai permasalahan.

\section{Tindakan Simbolis dalam Sistem} Pemerintahan

Implementasi teori interaksionisme simbolik dalam kajian sejarah nampak dari perilaku Raja-raja di Indonesia melakukan legitimasi kekuasaan, dengan mengklaim sebagai keturunan dewa dan memiliki wahyu. Legitimasi di sini sebenarnya hanya sebagai simbol untuk mencari pengaruh dalam masyarakat dan dianggap memiliki wibawa atau kharisma. Contohnya seperti Hayam Wuruk yang mengakui bahwa dirinya merupakan keturunan Dewa Wisnu, Ken Arok sebagai sarana legitimasi kekuasaan, Ia mengakui sebagai keturunan Dewa Sywa.

\section{Pemaknaan dalam peristiwa sejarah}

Peristiwa Kerusuhan Mei 1998 yang terjadi di berbagai kota di Indonesia, seringkali muncul pertanyaan-pertanyaan sebelum peristiwa itu berhasil diungkap seperti:
Mengapa terjadi, sebabnya apa, pelakunya siapa, kapan itu terjadi, dan lain-lain. Dari pertanyaan-pertanyaan tersebut dapat menjadi bukti bahwa peristiwa Kerusuhan Mei 1998 yang terjadi di berbagai kota di Indonesia masih memiliki makna yang belum bisa diungkapkan kebenarannya. Oleh karena itu perlu untuk dinterpretasi atau ditelaah kembali data yang ada agar kebenaran dibalik makna peristiwa Kerusuhan Mei 1998 yang terjadi di berbagai kota di Indonesia bisa diungkap.

6. Pemaknaan pada simbol-simbol dalam seni arsitektur

a. Candi merupakan monumen pemakaman yang mana di dalamnya memiliki simbol-simbol yang memiliki nilai-nilai historis sangat tinggi, seperti batu lingga dan yoni, bentuk atap candi yang berupa stupa, patung-patung yang merupakan peninggalan budaya hindu dan budha serta relief yang mengandung pemaknaan dari isi ceritera yang disampaikan. Candi memiliki tiga bagian yaitu: kepala candi, badan candi dan kaki candi, sehingga keseluruhan bentuk candi adalah merupakan lambang dari sebuah gunung, yaitu gunung mahameru. Gunung memiliki arti tempat tinggal para dewa. Lingga dan Yoni melambangkan kesuburan, sehingga lingga menjadi simbol alat kelamin laki-laki sedangkan yoni merupakan simbol alat kelamin perempuan (Budiono Herusatoto, 2008:188).

b. Patung yang terdapat di dalam candi merupakan simbol dari 
trimurti dalam ajaran agama Hindu dan Budha yaitu kepercayaan terhadap Dewa Brahma sebagai pencipta, Dewa Wisnu sebagai pemelihara dan Dewa Sywa sebagaii pengrusak. Patung Nandi (sapi) yang terdapat di Candi Prambanan merupakan simbol kendaraan Dewa Wisnu, sehingga dapatb diketahui bahwa candi tersebut bercorak Hindu. Patung Airlangga yang menaiki burung garuda yang ada di Museum Purbakala Trowulan merupakan simbol perwujudan Dewa Wisnu. Hal tersebut nampak dari simbol burung garuda merupakan kendaraan dari Dewa Wisnu.

c. Simbolisme yang berupa candrasangkala yaitu tahun dimulainya pembangunan, yang terdapat di bangunan-bangunan sejarah seperti candi, keraton, museum, monumen, prasasti, dan lain-lain. Contoh Begawan Solo, yang disebut Sang Hyang Mahawan artinya dewa jalan. Tahun Candrasangkalanya 238, angka 2 dilambangkan dengan naga, angka 3 dilambangkan dengan katingal dan angka 8 dilambangkan dengan boja, sehingga candrasangkala 238 memiliki arti Naga-Katingal-Boja. Simbolisme lainnya dari Begawan Solo memiliki tahun Surya-sangkala 231 artinya Rupa-WeddaningPanembah.

d. Simbolisme dalam seni arsitektur nampak pada bentuk atap candi, pura, masjid dan gereja yang berbentuk segitiga maupun lingkaran. Bentuk segitiga memiliki arti mahameru, yaitu gunung tempat bersemayamnya para dewa, sedangkan bentuk lingkaran memiliki arti bulan yang merupakan perwujudan jiwa. Oleh karena itu candi, pura, masjid dan gereja merupakan tempat suci, sebagai tempat peribadatan (Djoko Soekiman, 2000:286).

7. Pemaknaan pada simbol-simbol dalam Relief

a. Perhiasan-perhiasan yang berbentuk ukiran atau relief dan patungpatung yang terdapat pada lekuklekuk candi juga memiliki mengandung simbol-simbol yang memiliki makna. Perhiasan yang terdapat di candi terdiri dari kala (kepala singa) yang dipasang di atas lekuk dan dihubungkan dengan dua kepala makara di bawah lekuk dengan dua pengikat sepanjang dinding lekuk. (Prijohutomo, 1953:165).

b. Hiasan dinding yang berupa ukiran atau relief pohon hayat atau pohon kehidupan dengan berbagai binatang atau satwa disebut kalpataru. Simbol tersebut melambangkan alam seisinya yang merupakan sumber kehidupan manusia. Relief simbol kalpataru tersebut terdapat pada candi Mendut yang sekarang dijadikan sebagai simbol pelestarian lingkungan hidup Indonesia (Budiono Herusatoto, 2008:189).

8. Pamaknaan dalam nama-nama tokoh-tokoh sejarah

Nama-nama raja dari kerajaan Hindu, Budha dan Islam memiliki 
gelar-gelar khusus, yang merupakan simbol dari legitimasi kekuasaannya. Untuk Raja dari Kerajaan Hindu dan Budha selalu menggunakan namanama dewa sedangkan untuk raja dari kerajaan Islam menggunakan nama-nama nabi atau rasul. Kerajaan yang dipimpin oleh raja-raja keturunan Panembahan Senopati memiliki gelar "Ingalogo Sayidin Panatagama" yang artinya Senapati di Medan Perang dan Tuanku Penata Agama. Contohnya: Sri Sultan Hamengkubuono artinya Tuanku memangku dunia/jagad dan penata agama. Mangkunegaran artinya memangku kekuasaan.

9. Tindakan Simbolis pada peristiwa-peristiwa penting

a. Pada awal zaman Hindu yang ditandai dengan dimulainya tarikh Caka, yan dimulai pada Tahun $78 \mathrm{M}$, pemberian hadiah dari raja kepada daerah-daerah yang berjasa berupa tanah perdikan, selalu ditandai dengan meletakkan batu besar yang bentuknya seperti daun tunjung yang memuat piagam.

b. Prasasti merupakan batu pahatan yang berisi berita-berita penting seperti kunjungan raja, dibangunnya candi atau bangunan suci, kebijakan yang di buat raja dan sebagainya. Prasasti ini merupakan wujud simbolis dalam peristiwa-peristiwa penting, warisan dari kebudayaan India.

10. Pemaknaan dalam seni sastra

a. Pemaknaan dalam seni sastra nampak dalam sumber sejarah tertulis yang berupa kitab-kitab seperti syair, gancaran, kakawin, dhandhanggulo. Seperti isi dari tembang dhandanggulo berikut ini:

Sanepane wong urip puniki, Aneng donya iku umpamanya, Mung kaya wong mampir ngombe,

Umpama manuk mabur, lepas saking kurunganeki

Pundi mencoke benjang, ojo kongsi kliru, Upama wong jan-sinajan, Ora wurung mesti bali mulih, mring asal kamulanya

(Ir. Sri Mulyono, 1979:185)

Isi Tembang dhandhanggulo memiliki simbol dan pandangan hidup orang jawa yang berisi pesan moral yaitu "bahwa manusia hidup di dunia hanyalah sesaat saja seperti orang singgah minum di kedai dalam perjalanan yang panjang menuju kehidupan yang baka (Budiono Herusatoto, 2008:189).

b. Di samping itu juga terdapat seloka yang berbunyi " Bhinneka Tunggal Ika Tan Hana Dharma Mangrwa" yang artinya meskipun berbeda-beda tetapi tetap satu jua. Seloka tersebut terdapat dalam kitab sutasuma yang merupakan peninggalan dari kerajaan Majapait dan sekarang dijadikan sebagai lambang pemersatu bangsa.

c. Bendera gula kelapa yang merupakan bendera kerajaan Majapait memiliki simbol bahwa Merah berarti berani dan putih artinya suci, sehingga dijadikan sebagai lambang sifat berani 
dalam membela kebenaran yang suci. Warisan lambang bendera kerajaan Majapahit tersebut saat ini dipakai sebagai lambang bendera kesatuan Negara Republik Indonesia. (Budiono Herusatoto, 2008:191).

d. Raja Mangkunegaran IV mewariskan ajaran mencari menantu yang tertuang dalam Serat Warayadya. Mengajarkan adanya empat hal sebagai dasar pertimbangan dalam mencari menantu yang dikenal dengan ungkapan: bobot, bebet, bibit dan tatariman. Bobot sebagai simbol kedudukan sosial atau kekayaan, Bebet sebagai simbol latar belakang keluarga, Bibit sebagai simbol asal usul atau keturunan sedangkan tatariman sebagai simbol dari hadiah (Team, 2005:77).

Teori interaksionisme simbolik digunakan untuk mengungkap atau memberi makna terhadap simbol-simbol yang terdapat dalam kehidupan sosial masyarakat sehari-hari. Dalam kajian sejarah membutuhkan obyek kajian yang berupa kondisi sosial budaya yang merupakan setting munculnya suatu peristiwa sejarah, yang mana di dalamnya terdapat banyak simbol-simbol yang terbentuk akibat adanya interaksi sosial budaya. Untuk dapat mengetahui akan gambaran kondisi kehidupan masyarakat yang utuh perlu untuk memberi makna terhadap simbol-simbol tersebut yang kemudian diinterpretasi sesuai dengan permasalahan yang sedang dikaji. Dalam menginterpretasi dengan analisis yang akurat agar diperoleh kebenaran yang valid.

Ilmu sejarah sebagai bagian dari ilmu sosial membutuhkan teori interaksionisme simbolik dalam mengungkap kebenaran peristiwa masa lampau untuk memaknai simbol-simbol yang terdapat di dalam setiap realitas kehidupan manusia. Oleh sebab itu makna yang ada di setiap peristiwa sejarah memiliki hubungan keterkaitan dan bersifat integral yang tidak dapat dipisahkan. Hal tersebut dikarenakan setiap peristiwa sejarah memiliki keunikan yang dibatasi oleh ruang dan waktu.

\section{Pemaknaan dalam Pembelajaran Sejarah}

Guru sejarah memiliki peran yang begitu penting dalam menyampaikan materi pembelajaran agar dapat dipahami siswa-siswanya. Tujuan pembelajaran yang ingin dicapai dalam proses pembelajaran sejarah tidak hanya pada tataran pemahaman konsep saja, akan tetapi dari pemahaman pengatahuan yang dimiliki oleh siswa dapat memberikan pengaruh terjadinya perubahan sikap atau change behaviour. Oleh karena itu tugas seorang guru sejarah tidak hanya menstransfer pengatahuan saja tetapi juga mampu memberikan penanaman nilai, sehingga dari penanaman nilai tersebut dapat memberikan soft skill, sehingga siswa dapat memiliki kepekaan dalam menghadapi berbagai permasalahan yang terjadi di masa kini maupun yang akan datang. 
Pembelajaran sejarah memiliki sasaran antara lain memberikan gambaran yang tepat tentang konsep waktu, ruang dan masyarakat, keterkaitan antara masa sekarang dan masa lampau, antara wilayah lokal dengan wilayah lain yang jauh letaknya, antara kehidupan perseorangan dan kehidupan nasional, antara kehidupan dengan kebudayaan masyarakat lain dimanapun dalam ruang dan waktu. Sasaran lainnya yaitu membuat masyarakat mampu mengevaluasi nilai-nilai dan hasil yang telah dicapai oleh generasinya. Ilmu sejarah memiliki peran yang sangat strategis dalam mengukur keberhasilan serta kegagalan yang telah dicapai pada masa sekarang, sehingga generasi muda diharapkan memiliki kepekaan dalam menghadapi berbagai permasalahan dalam masyarakat baik politik, ekonomi, sosial maupun budaya.

Sasaran yang ingin dicapai dalam pembelajaran sejarah untuk menanamkan sikap intelektual, sehingga dapat mengembangkan kemampuan anak untuk memformulasikan penilaian yang obyektif, mempertimbangkan setiap bukti dengan penuh kehati-hatian dan menganalisis bukti-bukti secara tepat. Dengan demikian pembelajaran sejarah dapat melatih siswa agar akurat dalam menyusun pemahaman yang komprehensif.

Pembelajaran sejarah juga memiliki sasaran mengajarkan prinsip-prinsip moral, sehingga dapat dikembangkan pengatahuan yang bersifat praktis tidak hanya sebatas konsep-konsep saja. Ilmu sejarah dapat memaparkan perbuatan-perbuatan yang baik maupun yang buruk, menunjukkan kebenaran dan kesalahan melalui contoh-contoh kongkret yang terjadi dalam kehidupan manusia dari masa ke masa. (Kochhar, 2008:31-33).

Guru sejarah memiliki peran yang sangat penting dalam proses keseluruhan pembelajaran sejarah. Kualitas terhadap pembelajaran sejarah sangat tergantung pada peran gurunya, sehingga seorang guru sejarah harus dapat menciptakan suasana pembelajaran menjadi menarik dan menyenangkan. Untuk menciptakan pembelajaran sejarah tersebut menarik dan menyenangkan perlu didukung adanya beberapa faktor yaitu metode pembelajaran yang tepat sesuai dengan materi dan karakteristik siswanya, media yang menarik serta membantu dalam kemudahan dalam penyampaian materi serta sumber belajar yang bervariatif, sehingga tidak menyebabkan siswa menjadi bosan.

Tanggung jawab guru sejarah yang paling utama adalah mampu menginterpretasikan berbagai peristiwa masa lampau secara obyektif dan memiliki makna kepada siswasiswanya. Hal tersebut bertujuan agar siswa dapat memiliki pemahaman yang akurat, sehingga dapat memiliki sikap intelektual terutama dalam emngembangkan sikap kritis dan peka terhadap peristiwa-peristiwa yang terjadi dalam kehidupan sehari-hari dalam berbagai bidang kehidupan. Seorang guru sejarah dalam menginterpretasikan peristiwa-peristiwa 
sejarah harus mampu memahami terhadap pemaknaan dari setiap peristiwa sejarah sera mampu mancari hubungan keterkaitan antar satu dengan yang lain, sehingga makna yang dimiliki oleh setiap peristiwa sejarah tidak bersifat otonom tetapi berkesinambungan dengan peristiwa yang lainnya.

Di dalam memberikan materi pembelajaran sejarah, seorang guru sejarah harus mampu mengkaitkan antara masa lampau dengan masa kini dan masa yang akan datang. Dengan demikian pemaknaan yang ada di dalam peristiwa-peristiwa sejarah bersifat integral serta memiliki satu kesatuan yang tidak terpisah-pisah atau terkotak-kotak. Pemahaman siswa terhadap materi sejarah juga bisa menyeluruh dan bersifat obyektif. Hal tersebut memilki pengaruh yang begitu besar bagi keberhasilan ilmu sejarah dalam memberikan penanaman nilai moral maupun intelektual.

Untuk dapat mengembangkan kualitas pembelajaran sejarah secara optimal harus didukung juga oleh kualitas guru sejarahnya, sebab keberhasilan suatu proses pembelajaran terletak pada peran dan fungsi guru dalam mengajar yang memiliki peran sebagai Manage of Institution. Ada dua faktor yang dapat dikembangkan oleh guru sejarah dalam mendukung proses pembelajarannya di kelas yaitu penguasaan materi, seorang guru sejarah harus mampu menguasai dan memperluas pengetahuan historisnya serta menguasai dasar-dasar ilmu sosial seperti geografi, sosiologi, ekonomi, filsafat, dan lain-lain. Ilmu pengetahuan tersebut dapat memperkuat dan menjadi ilmu bantu dalam pembelajaran sejarah.

Di samping itu seorang guru sejarah juga harus menguasai teknik pengajaran, yang berupa variasi berbagai macam metode dan teknik pembelajaran sejarah. Metode tersebut digunakan dalam menciptakan suasana pembelajaran yang menyenangkan, sehingga harus selalu memiliki kreativitas yang sangat tinggi baik dalam mem-berikan kejutan maupun dalam berceritera. Metode pembelajaran sejarah yang dapat diterapkan oleh guru sejarah dapat berupa metode bercerita, sosio drama, role playing, diskusi, tanyajawab, observasi, simulasi, fieltrip, dan lain-lain.

Agar pembelajaran sejarah menyenangkan perlu didukung oleh adanya media pembelajaran yang berfungsi sebagai alat bantu dalam penyampaian materi pembelajaran. Media yang bisa digunakan dalam pembelajaran sejarah antara lain berupa peta, grafik, gambar, chart, bagan tabulasi, film, artikel koran maupun internet, radio, gambar bergerak, televisi, globe, foto, miniatur peninggalan sejarah, dan lain-lain. Media pembelajaran tersebut dapat membantu siswa dalam memperoleh pengalaman tentang pengetahuan sejarah secara langsung, sehingga mampu menumbuhkan dan mengembangkan kesadaran akan peristiwa sejarah yang dibatasi oleh ruang dan waktu.

Dengan demikian dalam diri siswa akan tumbuh kesadran dan motivasi diri untuk memiliki kepekaan terhadap realitas hidup 
yang di hadapi sehari-hari. Pemilihan media pembelajaran harus disesuaikan dengan karakteristik siswanya, latar belakang kemampuan intelegensinya, minat dan kebutuhan para siswanya.

Guru sejarah memiliki peran yang sangat penting dalam mengajar sekaligus membimbing siswanya di kelas, sehingga keberhasilan dan kegagalan proses pembeljaran sejarah tergantung pada perannya. Hal itu disebabkan guru yang membuat perencanaan program pembelajaran sekaligus yang melaksanakan program tersebut di lapangan. Oleh sebab itu seorang guru sejarah harus memiliki pengetahuan yang luas sehingga mampu menyaring informasi sebanyak mungkin, serta harus memiliki kesadaran yang sangat tinggi dalam mengembangkan sikap kritis dan kepekaan terhadap peristiwa-peristiwa yang aktual dalam kehidupan masyarakat. Melatih siswa untuk mengembangkan sikap kritis tersebut, sehingga peristiwa aktual itu dapat menjadi kekuatan dalam pembelajaran sejarah.

\section{Penutup}

Teori interaksionisme simbolik sangat erat kaitannya dalam penelitian kualitatif yang digunakan untuk menjelaskan tingkah laku manusia melalui analisis makna. Terbentuknya makna dan simbol dalam kehidupan masyarakat sebagai akibat adanya interaksi sosial budaya. Untuk itu dalam teori interaksionisme simbolik ini yang dikaji perilaku manusia, realitas sosial dan budaya.

Ilmu sejarah sebagai bagian dari ilmu sosial membutuhkan teori interaksionisme simbolik dalam mengungkap kebenaran peristiwa masa lampau untuk memaknai symbol-simbol yang terdapat di dalam setiap realitas kehidupan manusia. Oleh sebab itu makna yang ada di setiap peristiwa sejarah memiliki hubungan keterkaitan dan bersifat integral yang tidak dapat dipisahkan. Hal tersebut dikarenakan setiap peristiwa sejarah memiliki keunikan yang dibatasi oleh ruang dan waktu.

Di dalam penelitian sejarah dengan menggunakan metode kualitatif, yang mana obyek kajiannya adalah fenomena-fenomena sejarah membutuhkan teori interaksionisme simbolik dalam mengungkap makna dari simbol-simbol yang terdapat dalam kehidupan masyarakat, sehingga kebenaran dibalik peristiwaperistiwa sejarah dapat diung-kap secara utuh dan menyeluruh.

Peran guru sejarah begitu penting dalam proses keberhasilan pembelajaran sejarah, sehingga dituntut untuk memiliki kesadaran yang sangat tinggi dalam menginterpretasikan makna di setiap peristiwa sejarah secara obyektif. Dengan demikian pemaknaan terhadap peristiwa-peristiwa sejarah yang merupakan materi pembelajaran sejarah dapat bersifat integral atau memiliki keterkaitan dan kesinambungan yang di batasi oleh ruang dan waktu. Sasaran pembelajaran sejarah juga dapat tercapai terutama dalam 
114 A g a s ty a - Vol. 1, Januari 2011

memberikan penanaman nilai intelektual dan moral agar siswa memiliki kesadran yang tinggi dalam mengembangkan sikap kritis dan peka terhadap realitas yang ditemuai sehari-hari. 


\section{Daftar Pustaka}

Budiono Herusatoto. 2008. Simbolisme Jawa. Yogyakarta: Ombak.

Djoko Soekiman. 2000. Kebudayaan Indis. Yogyakarta: Bentang.

Faizal Sanapiah. 1990. Penelitian Kualitatif Dasar-dasar dan Aplikasi. Malang: YA3 Malang.

Hildred, Geertz. 1985. Keluarga Jawa. Jakarta: Grafiti Perss.

Kikyo. 2010. Teori Interaksionisme Simbolik-George Herbert Mead. http://www.kikyo.blog.uns.ac.id /2010/04/03/teoriinteraksionisme-simbolik/ (diunduh 5 Januari 2011).

Kochhar S.K. 2008. Teaching of History. Jakarta: PT Grasindo.

Koentjaraningrat. 1997. Manusia dan Kebudayaan di Indonesia. Jakarta: Djambatan.

Louis Gottschalk. 2006. Mengerti Sejarah. Jakarta: UI-Press.

Prijohutomo. 1953. Kebudayaan Hindu di Indonesia: Sejarah Kebudayaan Indonesia Jilid II. Jakarta: J.B. Wolters.

Ricklefs, M.C. 2002. Yogyakarta Di Bawah Sultan Mangkubumi 1749-1792. Yogyakarta: Mata Bangsa.

Riyadi Suprapto. 2007. Mengenal Singkat Teori Interaksionisme Simbolik.

http://www.averroes.or.id/ research/teori-interaksionismesimbolik.html.

(diunduh 5 Januari 2011).

Rustopo. 2007. Menjadi Jawa. Yogyakarta: Ombak.

Suriasumantri S. Jujun. 1986. Ilmu dalam Perspektif Moral, Sosial dan Politik. Jakarta: PT. Gramedia.

Team. 2005. Kajian Sejarah Mikro Sebagai Muatan Lokal. Surakarta: UNS Press

Waluyo J. Herman. 2002. Pengantar Filsafat Ilmu. Salatiga: Widya Sari Press.

Yuda Triguna. 2000. Teori Tentang Simbol. Denpasar Timur: Widya Dharma.

http://fkip.uki.ac.id/index.php?optio n.com content\&view.article\&id. 78:penelitian-lintasbudaya\&catid.41:artikel\&item (diunduh 5 Januari 2011). 